\title{
Correction to: Mutations in the nucleotide binding and hydrolysis domains of helicobacter pylori MutS2 lead to altered biochemical activities and inactivation of its in vivo function
}

Prashant P. Damke1, Rajkumar Dhanaraju', Stéphanie Marsin $2,3,4$, J. Pablo Radicella ${ }^{2,3,4^{*}}$ and Desirazu N. Rao ${ }^{1 *}$

\section{Correction to: BMC Microbiol \\ https://doi.org/10.1186/s12866-016-0629-3}

Following publication of the original article [1], the authors notified us of an error in the presentation of Fig. 6G.

In the published version panels 5 and 6 of the Fig. $6 \mathrm{G}$ are similar, but the nuclease assays contained two different nucleotide cofactors. During assembly and handling of the images for this figure, the same image, albeit with different contrast, was used unintentionally for panels 5 and 6 . This image corresponded to panel 6 .

The assay addressed the effect of ADP (Fig. 6G, panel 5) and ATPyS (Fig. 6G, panel 6) on the nuclease activity of HpMutS2 on Holliday junction substrate. In absence of cofactors (Fig. 6D, and 6G panel 1), HpMutS2 degrades Holliday junction at $26.49 \pm 3.95 \mathrm{pM}$ min-1 (Table 3). The addition of ADP and ATP $\mathrm{SS}$ reduced the nuclease activity of HpMutS2 by $\sim 1.5$-fold, resulting in the cleavage rates of $18.85 \pm 1.9 \mathrm{pM}$ min- 1 and $17.44 \pm$ $0.84 \mathrm{pM}$ min- 1 , respectively.

The quantification of the assays shown in Fig. 6D were derived from the correct gel images and therefore Fig. 6D and DNA cleavage rates presented in Table 3 remains unchanged.

Corrected Figure ${ }^{\wedge} 6$ is presented below:

\section{Author details}

${ }^{1}$ Department of Biochemistry, Indian Institute of Science, Bangalore 560012 India. ${ }^{2}$ CEA, Institute of Cellular and Molecular Radiobiology, Fontenay aux Roses, France. ${ }^{3}$ INSERM UMR967, Fontenay aux Roses, France. ${ }^{4}$ Universités Paris Diderot et Paris Sud, Fontenay aux Roses, France.

Published online: 19 August 2019

\section{Reference}

1. Damke et al. (2016) Mutations in the nucleotide binding and hydrolysis domains of Helicobacter pylori MutS2 lead to altered biochemical activities and inactivation of its in vivo function (2016) 16:14 DOl: https://doi.org/1 $0.1186 / \mathrm{s} 12866-016-0629-3$

* Correspondence: pablo.radicella@cea.fr; dnrao@biochem.iisc.ernet.in

${ }^{2}$ CEA, Institute of Cellular and Molecular Radiobiology, Fontenay aux Roses, France

'Department of Biochemistry, Indian Institute of Science, Bangalore 560012,

India

Full list of author information is available at the end of the article

(C) The Author(s). 2019 Open Access This article is distributed under the terms of the Creative Commons Attribution 4.0 International License (http://creativecommons.org/licenses/by/4.0/), which permits unrestricted use, distribution, and reproduction in any medium, provided you give appropriate credit to the original author(s) and the source, provide a link to the Creative Commons license, and indicate if changes were made. The Creative Commons Public Domain Dedication waiver (http://creativecommons.org/publicdomain/zero/1.0/) applies to the data made available in this article, unless otherwise stated. 


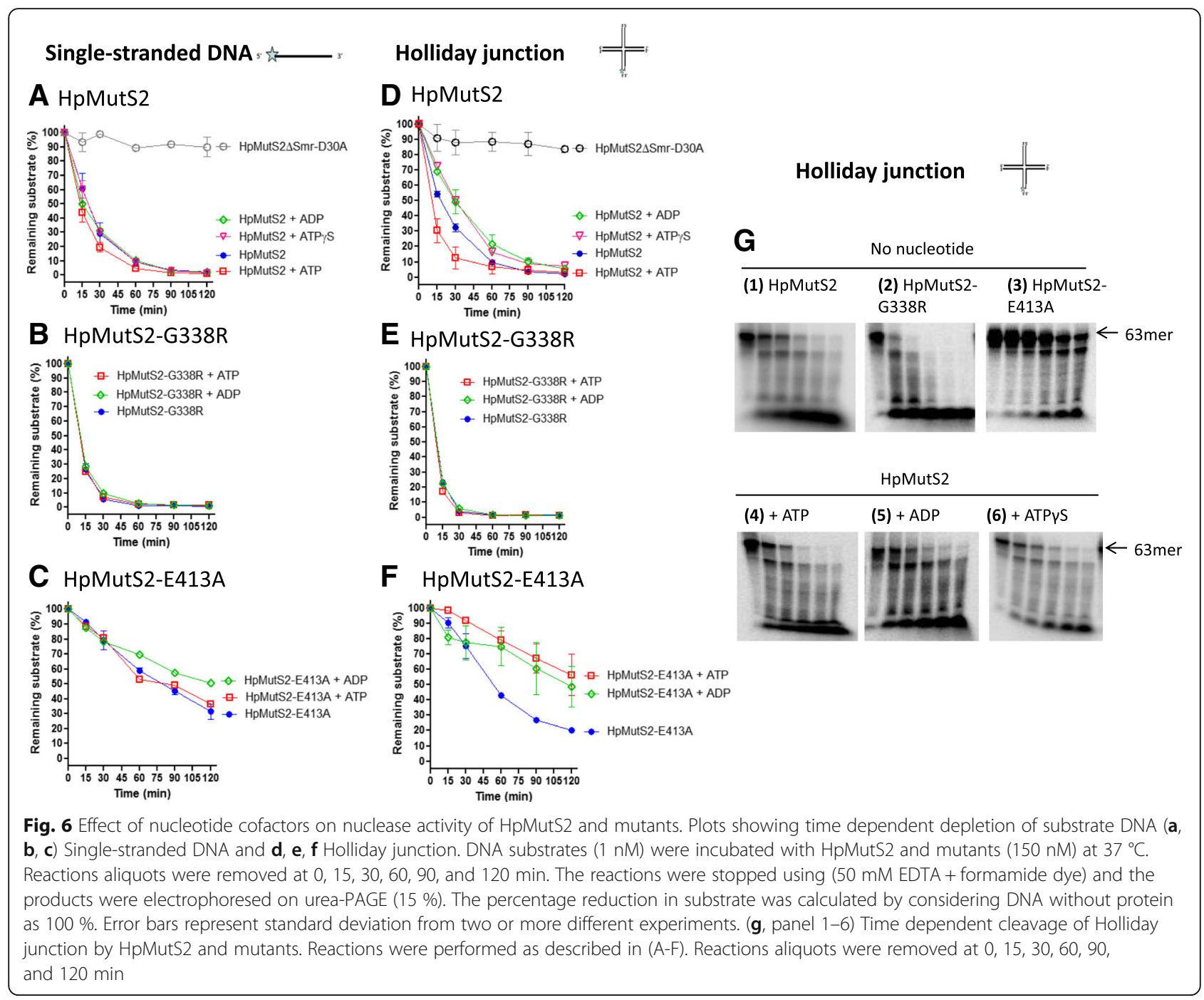

